\title{
ANALYSIS OF ILLOCUTIONARY ACT IN THE MOVIE "YOU ARE MY HOME" ENGLISH SUBTITLE
}

\author{
Friska Sari Luksiana Hutajulu, Herman \\ Nommensen HKBP University, Indonesia \\ friskaslhutajulu@gmail.com, herman@uhn.ac.id
}

\begin{abstract}
An utterance to explain how speakers use language to accomplish intended actions and how the hearers infer intended meaning from what is said called as a speech acts. The study of speech act is very important for us because it can make us comprehend what message that discovered in every utterance. Austin (1962) stated that in uttering a sentence, a speaker is generally involved in three level of speech acts, they are locutionary act, illocutionary act, and perlocutionary act. But for this occasion, this research focuses in analyzing Illocutionary Act in the movie "you're my home" that presented by EvimSensin. This research used the combination between qualitative and quantitative approach. The research problem will be discussed are: First, What types of Illocutionary acts are found in "You are my home" movie English subtitle? Second, what is the most dominant types of Illocutionary acts used in "You are my home" movie English subtitle? Finally, the purposes of this research are to find out the types of Illocutionary acts and to analyze the most dominant Illocutionary acts produced in "You are my home" movie English subtitle.
\end{abstract}

Keywords: Illocutionary act, speech act, subtitle.

\section{INTRODUCTION}

In modern era, especially in era where the development of technology is very rapidly make communication interstate there is no limit. Many people believe that the significance of communication is like the importance of breathing. Indeed, communication facilitates the spread of knowledge and forms relationship between people by using language. Language is as the tool of communication that has the essential part in making communication. Because language has the important role in communication, so there is a specific study to discuss language.

A study of language that discuss how speaker used language to accomplish intended actions and how hearers infer intended meaning from what is said called Speech Acts. In speech acts there is a relation to utterances that uttered by people.

According to Austin (1983: 236) that in uttering a sentence, a speaker is generally involved in three different acts: Locutionary act, Illocutionary act, and Perlocutionary act. Meanwhile, there also five types of Illocutionary act, they are: representative, directive, commissive, declarative, and expressive. All the types of speech events can we find in communication, dialogue especially in movie.

In the movie, we can find a motion picture which considered especially as a source of entertainment. In the movie, many types of speech acts are performed by the characters. And the researcher is interest to analyze types of speech acts especially Illocutionary acts in the movie. At the researcher hoped by this paper will give a lot of knowledge about speech acts and also to the other researcher who make a deep research about speech acts. 


\section{THEORITICAL FRAMEWORK}

\subsection{Definition of Speech Acts}

Speech Acts is an utterance to explain how speaker use language to accomplish intended actions and how the hearers infer intended meaning from what is said. Speech act performs when people make utterances such as compliment, greeting, request, complaint, invitation, apologize, or refusal. The study of speech act is very importance for us. Hence, Yule (1996:47) as cited in Herman (2015:43) stated that when people speak a language, they will perform an action. Actions which are performed via utterances are generally called speech acts. The one importance of studying speech act is to make us comprehend what message that discovered in every utterance. Speech act also decided by the language ability of speaker to convey the message in communication. Hence, we can understand about the meaning of speech act clearly. According to Austin (1962:199) as cited in Herman (2015:43) defined that the utterances of the speaker can be divided into three meanings, they are Locutionary act, illocutionary act, and perlocutionary act.

\subsection{Types of Speech Acts}

Based on theory of Austin, speech acts is categorized into three types. Should be clear we can discuss one by one.

\section{Locutionary Act}

Locutionary act is the basic act of utterance, or producing a meaningful linguistic expression. In other words, locutionay act can be defined as the act of making a meaning full utterance and using a referring expression. The speaker usually uses the identifiable expression to produce a meaningful expression to the hearer. In other words, locutionary act is an act to produce meaningful and understandable utterances. Every utterance expressed is meaningful and understandable so the utterance will be identified further to decide if it is illocutionary act or perlocutionary act. The speaker who tounge tied can't speak properly so he or she failed in making locutionary act because the language is not understandable. In short, Locutionary act is the actual form of words used by the speaker and their semantic meaning (directly uttered).

\section{Illocutionary Act}

Illocutionary act is a complete speech act, an act of doing something which means the specific purpose of the speaker's intention in mind such as promising, stating, commanding, denial, prediction, request, confirming, etc. There are five types of Illocutionary act, representative, directive, commissive, declarative, and expressive. Should be clear we can discuss each of type.

\section{$\checkmark$ Representatives}

Kinds of speech act that state what the speaker believes to be the case or not. It can be statements of fact, assertions, conclusions and descriptions. In using a representative, the speaker makes words fit the world (of belief). The examples would be: affirm, believe, conclude, report.

\section{$\checkmark$ Directives}

Kinds of speech act that the speakers use to get someone else to do something. They express what the speaker wants. They are commands, order, requests, and 
suggestions. In using a directive, the speaker attempts to make the world fit the words (via hearer). Shortly, directive is the speaker try to do something. The examples would be: ask, challenge, command and request.

\section{$\checkmark$ Commissive}

Kinds of speech act that speakers use to commit themselves to some future action. They are promises, threats, refusals, pledges and they can perform by the speaker alone or by the speaker as a member of a group. In using a commisive, the speaker undertakes to make the world fit the words (via the speaker).The examples would be: bet, guarantee, pledge, promise, swear, etc.

\section{$\checkmark$ Expressive}

Kinds of speech act that state what the speaker feels. They express psychological states and can be statements of pleasure, pain, likes, dislikes, joy or sorrow. They can be caused by something the speaker does or the hearer does but they are about the speaker's experience.

\section{$\checkmark$ Declaration}

Kinds of speech act that change the world via their utterance. In using a declaration, the speaker changes the world via words.

Example :

Priest: I now pronounce you husband and wife.

\section{Perlocutionary Act}

Perlocutionary act is the reaction of the hearer, the consequences of $\mathrm{s}$ something,intended or not. The effect after the speaker says something to the hearer; an act is performed as a reaction. The action of the hearer depends on what the speaker says. The effects may be actions, thoughts or feelings.

\section{RESEARCH METHODOLOGY}

\subsection{Research Design}

The researchers make the design of this research based on the combination between qualitative and quantitative approach. The researchers choose qualitative approach because based on the first problem of the research, the researchers want to analyze the types of Illocutionary Act based on the movie. And quantitative approach used to count dominant types of Illocutionary Act that found in the movie.

\subsection{Data Source}

The researchers got the data source from the movie English subtitle "You are my home". By this movie, the researchers checked the utterance that the characters said in movie. And then found out the Illocutionary act especially five types of Illocutionary act in the movie English subtitle that had the total duration on 01.40.18

\subsection{Technique of Collecting Data}

The activity in technique of collecting data, the researchers search the movie that has the subtitle using English language from YouTube that has the link easy to search it 
inLK21.ORG and after that the researchers analyzed Illocutionary act five types of Illocutionary act in that movie.

\subsection{Technique of Analyzing Data}

Based on the technique of collecting the data that has been done by the researchers, they use several steps: firstly, the researcher checks the utterance that the character said to the English subtitle that has shown under the screen. Secondly, the researchers analyzed and found Illocutionary act and five types of Illocutionary act in that movie and thirdly after the researcher analyze and categorize the types of Illocutionary act, the researchers count the dominant types of Illocutionary act in that movie subtitle.

\section{FINDINGS AND DISCUSSION}

\subsection{Research Findings}

4.1.1 Types of Illocutionary act Found in the Movie Subtitle 'You are my home'

After checking and analyzing the movie and categorize it to the types of Illocutionary act, the researchers found there are four types of Illocutionary act found in the movie 'You are my home' but there is no Declarative types in this movie. The researchers wrote the total utterances that uttered by the characters for about 216 utterances in the beginning until the end. In calculating of Illocutionary act, there are 78 representatives, 90 declaratives, 40 expressives and 8 commissives. These are the analysis types of illocutionary acts used to realize the illocutionary acts are presented and the researchers show only two excerpts in every analysis based on in the movie script as follow:

\section{a. Representatives act}

These excerpts below are the analysis of representatives act, just includes in asserting, informing, prohibiting and claiming.

\section{1) Informing}

In this movie, the researchers have found several utterances having the act of informing. The analysis of informing utterances explained bellow:

Utterances 1

Iskandar

: "Do you know why I'm never crying? I cried for days after she had left me and then I swore that I would never cry again. You don't know what that woman made me suffer."

\section{Utterances 2}

Leyla

: "I can't understand doctor."

Doctor

$$
\begin{aligned}
& \text { : "Senility. This means a variation of demensia. It can be } \\
& \text { seen at young ages too." }
\end{aligned}
$$

\section{2) Prohibition}

In this movie, the researchers have found several utterances having the act of prohibition. The analysis of prohibition utterances explained bellow:

Utterances 1

Leyla

: “Iskan, your hand is bleeding! Please don't! 


\section{Don't hurt yourself!"}

\section{3) Asserting}

In this movie, the researchers have found several utterances having the act of asserting. The analysis of asserting utterances explained bellow:

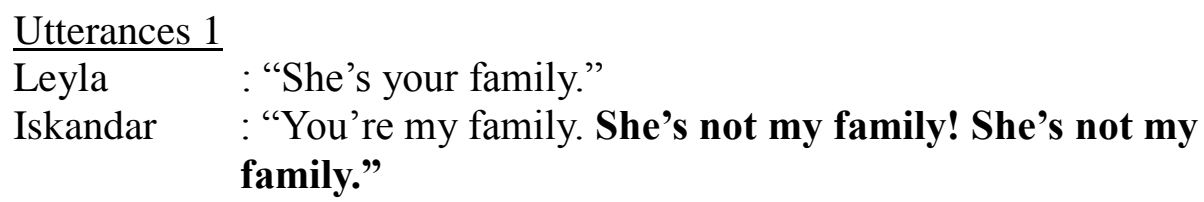

\section{Utterances 2}

Brick : "I'm your father. If I can't protect you, stay behind you, what kind of father am I?"

\section{4) Claiming}

In this movie, the researchers have found several utterances having the act of claiming. The analysis of claiming utterances explained bellow:

Utterances 1

Iskandar : "Leave it! You don't know her behind. But...

She threw me on the streets when I was 5 years old. You don't know who you are defending!"

\section{b. Directives}

This excerpts or utterances bellow is the analysis of directives act which includes of asking, warning, commanding, and requesting.

\section{1) Asking}

In this movie, the researchers have found several utterances having the act of asking. The analysis of asking utterances explained bellow:

\section{Utterances 1 \\ Iskandar : "How much does she owe you?" how much?" \\ Robby : :"Hundred thousand."}

\section{Utterances 2}

\section{Iskandar : "What did the doctor tell to you?"}

Leyla : "Nothing. He told me to come again in a week."

\section{2) Warning}

In this movie, the researchers have found several utterances having the act of warning. The analysis of warning utterances explained bellow:

\section{$\underline{\text { Utterances } 1}$}

Leyla : "Daddy, please forgive me. I beg you, forgive me."

Brick : "I wanted to see if you off myself! You played with my honor! How could I forgive you?" 


\section{3) Commanding}

In this movie, the researchers have found several utterances having the act of commanding. The analysis of command in utterances explained bellow:

Utterances 1

Brick

: "You're right! Stop leave it! You'll lear off what you served yourself."

Leyla : "Ahh Dad."

\section{Utterances 2}

Iskandar

: "She is my home and my life. If you take her for me, I won't be able to get back on my feet again."

Brick : "I sent her to the USA. She'll get a long lasting therapy there. Forget her!"

\section{4) Requesting}

In this movie, the researchers have found several utterances having the act of requesting. The analysis of requesting utterances explained bellow:

\section{Utterances 1}

Leyla :"Why, what happened?"

Jhon : "The carpenter ran away."

Leyla : "How come?"

Jhon : "I'll ask him how if I see him. We have to open this shop in one week. And I'm waiting themselves all by myself. And I broke my finger doing this man's job. Help Leyla...help!"

\section{c. Expressives}

These excerpts or utterances below are the analysis of expressive act, including thanking, apologizing, Greeting and Compliment.

\section{1) Thanking}

In this movie, the researchers have found several utterances having the act of thanking. The analysis of thanking utterances explained below:

Utterances 1

Iskandar : "You can keep the blanket."

Leyla : "Thank you."

\section{2) Apologizing}

In this movie, the researchers have found several utterances having the act of apologizing. The analysis of apologizing utterances explained bellow:

Utterances 1

Leyla : "Are you beating people with the car? I'm sorry."

Iskandar : "Why?"

Leyla : "Because I yelled at you last time."

\section{3) Greeting}


In this movie, the researchers have found several utterances having the act of greeting. The analysis of greeting utterances explained bellow:

\section{Utterances 1}

Leyla : "Hello, Eno!"

Eno : :We're screwed Leyla, we're screwed!"

Leyla : "Why, what happened?"

Eno : "The carpenter ran away."

\section{4) Compliment}

In this movie, the researchers have found several utterances having the act of compliment. The analysis of compliment utterances explained bellow:

Utterances 1

Leyla : "There are so many things that I want to tell you. I love you. I'm leaving you because of my oblivion. You are the most important thing that happened to me."

\section{d. Commissive}

This excerpts bellow is the analysis of commissive act, just includes of promising, and planning.

\section{1) Promising}

In this movie, the researchers have found several utterances having the act of promising. The analysis of promising utterances explained below:

Utterances 1

Leyla : "If I had a surgery?"

Doctor : "I wish I would. But you have to prepare yourself."

\section{2) Refusing}

In this movie, the researchers have found several utterances having the act of refusing. The analysis of refusing utterances explained below:

Utterances 1

Iskandar : "You're writing something. What are you writing?"

Leyla : "Won't tell you. What's this?"

\section{3) Planning}

In this movie, the researchers have found several utterances having the act of planning. The analysis of planning utterances explained bellow:

Utterances 1

Leyla : "And the chestfruit will be roasted on it.

Iskandar : "Yes, listen what I'm saying. We should build a room for guests here, so they can see the forest."

\subsection{Discussion}

After analyzing every utterance to the types of Illocutionary act, there are four types of Illocutionary act found in the movie. But in this video the researchers do not 
find the Declarative act. After analyzing the movie subtitle, the researcher found that the dominant types of Illocutionary act that found in the movie subtitle is Directive act. It can be proven for the analyses that had been done by the researchers. The next dominant types of Illocutionary act that occur in this movie subtitle is Representative acts.

\section{CONCLUSION}

After comprehend the theory about Speech Acts and analysis of the movie subtitle to the types of Illocutionary act, the researchers make some conclusion which states:

1. Based on the researchers' analysis it is only four types of Illocutionary act (Representatives, Directives, Expressive, Commissives) that occur in this movie subtitle.

2. In this video the researchers do not find the Declarative act.

3. Based on the movie subtitle, the researchers found that the dominant types of Illocutionary act that found in the movie subtitle is Directive Act.

\section{References}

Alan, Keith and Jaszczolt, Kasia M. (2012). The Cambridge Handbook of Pragmatics. New York: Cambridge University Press.

Cruse, D. Alan. (2000). Meaning in Language: An Introduction to Semantics and Pragmatics. New York: Oxford University Press Inc.

http://users.monash.edu.au/ kallan/papers/Speechatcs.html.On december25, 2018

Herman. (2015). Illocutionary acts analysis of Chinese in Pematangsiantar. International Journal of Humanities and Social Science Invention. ANED. 29.7722/0401202041048

Herman. (2018). Translation Procedures of the Subtitle of Film Tanah Air Beta from Indonesian into English. Discovery Journals: Indian Journal of Arts. PP. 32-42

Huang, Yan. (2007). Pragmatics. New York: Oxford University Press Inc

Jucker, A. H., \& Taavitsainen, I. (2008). Speech Acts in the History of English.Amsterdam: John Benjamins.

Kroeger, Paul R. (2018). Analyzing Meaning: An Introduction to Semantics and Pragmatics. Berlin: Language Science Press 